\title{
A study on the benefits of eco-friendly packaging on sustainable supply chain management in fast moving consumer goods industry
}

\author{
Wong Ker Xin ${ }^{1}$, Yap Kar Sen ${ }^{1}$, and Salini Devi Rajendran ${ }^{1 *}$ \\ ${ }^{1}$ Faculty of Business and Information Science, UCSI University, Jalan Menara Gading, 56000 Cheras, Kuala Lumpur, Malaysia.
}

\begin{abstract}
The focal of this qualitative study is to identify the benefits of eco-friendly packaging in sustainable supply chain management among FMCG industry regarding the relationship between benefits (cost reduction, brand image, legal compliance, and environmental friendly) that direct relate to sustainable supply chain management. In this study, interview was conducted and data has been collected through faceto-face interview and e-mail among the respondent who have working experience and knowledge in particular FMCG industry. Four hypotheses were set to study those four variables whether has a significant relationship with the benefits of eco-friendly packaging and sustainable supply chain management in FMCG industry. The collected data was analyzed through exploratory analysis to find out whether it can identify or determine the main variables related to the implementation of eco-friendly packaging on sustainable supply chain management towards FMCG industry in this study. The finding shows there is a direct relationship in which the benefit of eco-friendly packaging brings the company in developing more sustainable supply chain management.
\end{abstract}

\section{INTRODUCTION}

Fast-moving consumer goods (FMCG) are the large quantity, lower priced products that are in a faster speed that leave the retailing store shelf, such as supermarket, hypermarket, convenience store and others store which perform retail activities. In FMCG industry, they found out packaging is a benefit which not only plays the role of package the products; it also carries an effective communication between consumers and the brand owners [1].

Because of the benefits of packaging, there are some of the FMCG industry considers using eco-friendly packaging where consumers always concern about environmental impact. Eco-friendly packaging is introduced to support the sustainable development of the consumer firm [2]. With the changes of global social, economic and the rise of environmental concern, these leads the manufacturing firms to consider using ecofriendly packaging while doing their business. If manufacturing firms do not consider using eco-friendly packaging, it will affect the consumer purchasing intention on competitor product that is using eco-friendly packaging. Besides that, it might unable to compete with their competitors on time since Malaysia government has introduced some new policy regarding environmental concern.

Due to the rise of environmental concerns, there are more than 40 industry leaders have endorsed a global strategy plan on plastics production, use and recycling activities. The initiative is designed to ensure that $70 \%$ of plastic packaging is reused and recycled globally, up from today's recycling rate of $14 \%$. The remaining $30 \%$ of plastic packaging, equivalent to 10 billion garbage bags per year needs fundamental redesign and innovation, according to the group [3]. The risks of serious environmental and social effects created by poor oversaw of the supply chains can be avoided with improved practices that will also beneficial for the business [4].

At present, the Selangor government introduced the "No Plastics Bag" policy, it slowly boost the awareness of Eco-Friendly packaging in the customer's mind. Moreover, Malaysian consumers also concern about the changing trends and awareness of environment where Selangor government encourage all councils provide packaging ideas which include biodegradable packaging [5]. By using eco-friendly packaging, it helps to improve sales, develop sustainable supply chain and also reduce impacts towards the environment [6]. Furthermore, it also allows manufacturers to reduce its packaging cost, increase image of the company's brand, reduces impacts towards to the global environment, and transforming the human's consuming approaches for fast moving consumer goods [7]. Hence, it shows the benefits of using eco-friendly packaging on sustainability supply chain.

Although there are potential benefits of eco-friendly packaging, but some of the manufacturing firm still failed to develop eco-friendly packaging. According to

*Corresponding author's e-mail: salinidevi@ucsiuniversity.edu.my 
Norani Nordin (2015), lack of awareness and understanding become the barrier in sustainable supply chain development for manufacturers [8]. Thus, the manufacturers need to be alert to the awareness on ecofriendly packaging development. There are also several studies in the area of supplier selection and evaluation of supplier performance that uses artificial intelligence and fuzzy computing methods $[9,10]$.

Given that, sustainable supply chain management can be achieved by developing eco-friendly packaging as the packaging material for the product. It is vital to implement sustainable supply chain to reduce the impacts towards to the environment. Therefore, this study identifies the awareness of FMCG industry about the sustainable transformation will depend on what are the benefits of using the eco-friendly packaging for their products.

\section{METHODOLOGY}

In this study, exploratory study will be used to identify the main variables which related to the implementation of eco-friendly packaging on sustainable supply chain management towards FMCG industry in this study. An exploratory research defined as a type of research describes the problem that has not been clearly determined in the research [11]. Besides that, exploratory research is used to investigate or limited information to be identified about an area of interest which similar problem and research matters have been clarified in the earlier.

This research is conduct by using hypothesis testing with qualitative approach. Qualitative approach refers as a source of well-grounded, detail descriptions and explanation of processes in recognize local contexts [12]. One of the qualitative research methods is qualitative research interview.

In order to do this approach, interview will be take place by creating few questions to collect data. The question will be design based on the information collected from the company to test the variables. During the interview, higher-level management of FMCG Company that implementing eco-friendly packaging effectively will be selected as interviewee of this study. It is because those companies that implemented will show that it is practicing in real life. Thus, data collected will be reliable, valid and creditable for this study.

\subsection{Hypothesis}

H1: There is significant relationship between cost reduction and sustainable supply chain management in FMCG industry

H2: $\quad$ There is significant relationship between brand image and sustainable supply chain management in FMCG industry

H3: There is significant relationship between legal compliance and sustainable supply chain management in FMCG industry
H4: There is significant relationship between environmental friendly and sustainable supply chain management in FMCG industry.

\subsection{Data Collection Method}

Interview will act as a functional tool in order to collecting data for the qualitative study. To design an interview questions, it can be structured, semi-structured or unstructured types which can be take place through phone, face-to-face, or online interview which is the computer-based interviews [13].

In this study, method that used to collecting qualitative data is conducting face to face interview by using semi-structured interview questions. The data collection methods are non-probability sampling (purposive sampling), face-to-face interview (semistructured interviews) and data analysis procedures.

\subsubsection{Face-face interview}

In this study, a self-administered question is used as the data collection method for collecting the information as primary data. First, the invitation letter is send to FMCG industry representative who are using eco-friendly packaging for the company. Once invitation accepted, the interview session will be scheduled and using the self-administered questions. In this self-administered question will mention about what are the benefits on implementing eco-friendly packaging and how well it's going based on the higher-level management of FMCG company knowledge and experience. During the interview, data collection will be done through voice recording and in a written transcript.

\subsection{Sampling design}

\subsubsection{Sampling location}

The study location is FMCG industry in area of Klang Valley [14]. The samples will be focus on the FMCG industry who is implementing eco-friendly packaging effectively.

\subsubsection{Population}

The population in this study is the FMCG Company in Klang Valley where applied or committed to apply sustainable supply chain management.

\subsubsection{Sampling size}

The scope and nature are focus on eco-friendly packaging and benefit of sustainable supply chain in FMCG Company, at Klang Valley that the topic is direct and specific. The quality of data depends on the interviewee where they are the individuals who provide the usable information used for this study. Hence, this study consider to have (5) respondents that targeted the supply chain/ operations/ logistics manager and the 
employees of fast moving consumer goods (FMCG) company in 3 categories: (1) Food and beverage (2) Personal care (3) House care.

\subsubsection{Sampling technique}

Non-probability sampling design is adopted in this study. The collected data will be used in analyzing the benefits of sustainable supply chain management and how it has relationship with eco-friendly packaging. Data collection is focus on the target groups who have specific experiences and knowledge in order to provide the specific data needed.

The purposive sampling is adopted in this research is because it consumes lesser time and cost compared to other sampling methods. Purposive sampling (Judgmental sampling) is used in this study where data will only be collected from the decided individuals who is master on the field which having the first-hand knowledge of the topic [13].

\subsection{Interview}

Semi-structured interview is used as the data collection method for this study. According to Bryman and Bell (2011), in order to defined the answers in details, it require a question list as a semi-structured interview guide that derived from the research question [15]. However, respondent from interview will still able to answering the question in a free condition and in a wide range.

\subsection{Validity test}

Validity play an important role in a research study that require the test, scale, instrument, and others to be valid and reliable [16-19]. Validity, it refers to whether the respondents' research outcome present their knowledge with their job position and forms their perceptions on the skills and understandings on the research questions.

A list of qualitative interview questions has been designed as an interview guide for the selected three respondents from the same industry but different they are in different company, departments and job titles. Qualitative interview questions which were prepared for the interviewees whom are the packaging technologist from Dutch Lady Sdn. Bhd. and regional strategic buyer in packaging procurement from Nestle Group which associated with this study title, benefit of eco-friendly packaging towards sustainable supply chain management in fast moving consumer goods industry.

The semi-structured interview guide focused on the implements and benefits of eco-friendly packaging in fast moving consumer goods industry. The qualitative questionnaire will be separate into three sections, which include the interview guide; Section A, respondents' demographic profile; Section $\mathrm{B}$, understanding on sustainable supply chain management and eco-friendly packaging and; Section $\mathrm{C}$, benefit of eco-friendly packaging in sustainable supply chain management to the organization. Among the type of interview, this interview session carried out as semi-structured interview used as data collection method to validate the test.

\section{RESULT AND DISCUSSION}

In this study, the appointments and schedule with the respondent were made through e-mail address, LinkedIn, social media platform and text messages. Table 1 shows the background of the respondents of this study.

Table 1. Respondent's socio-demographic profile

\begin{tabular}{c}
\hline Characteristics \\
\hline Name \\
Age \\
Gender \\
Nationality \\
Education level \\
Job position
\end{tabular}

Attached department Job role

Research and Development

Packaging Development, Packaging issue, specification management Working experience 11 years

\subsection{Understanding of sustainable supply chain management and eco-friendly packaging}

Table 2 shows the respondents have a different understanding of sustainable supply chain management.

$\begin{array}{cc}\text { Respondent 2 } & \text { Respondent 3 } \\ \text { Ankit Singhai } & \text { Cheryl Tan } \\ 32 \text { years old } & \text { 32 years old } \\ \text { Male } & \text { Female } \\ \text { Indian } & \text { Malaysian } \\ \text { ndergraduate Master } & \text { Undergraduate Degree } \\ \text { Regional Strategic } & \text { Foods Category Planner } \\ \text { Buyer-Packaging } & \text { South East Asia } \\ \text { procurement } & \text { Australia (SEAA) } \\ \text { Procurement } & \text { Supply Chain }\end{array}$

Buyer

Innovation planning for SEAA countries, main liaison for Supply Chain 5 years 12 years

This is because they are from different perspective. Respondent 1 is from the research \& development perspective, Respondent 2 is from the procurement perspective, and Respondent 3 is from the supply chain planning perspective.

Table 2. Describe your understanding on sustainable supply chain management. 


$\begin{array}{ll}\text { Respondent 1: } & \begin{array}{l}\text { Manage and know about the whole process of supply chain management to } \\ \text { achieve sustainability }\end{array} \\ \text { Respondent 2: } & \begin{array}{l}\text { Supply chain will be the support function to meet business objective and helps } \\ \text { to achieve triple bottom line }\end{array} \\ \text { Respondent 3: } & \begin{array}{l}\text { Focus on raw and pack material sustainable sourcing and sustainable utilization } \\ \text { of resources throughout supply chain }\end{array}\end{array}$

Table 3 shows the companies of all respondents are having the similar sustainable supply chain practices.

Table 3. Describe how your company develops sustainability in the current supply chain.

\begin{tabular}{ll}
\hline Respondents & Answers \\
\hline Respondent 1: & Supplier selection, vendor selection, safety compliance \\
Respondent 2: & Value chain mapping, supplier selection, vendor selection, responsible \\
& sourcing, and specification \\
Respondent 3: & Supplier self-assessment and verification, sustainable agriculture program
\end{tabular}

Table 4 shows all respondents have similar understanding of eco-friendly packaging.

Table 4. Describe your understanding of eco-friendly packaging.

\begin{tabular}{cl}
\hline Respondents & Answers \\
\hline Respondent 1: & Talk about packaging material, recyclable, renewable and biodegradable \\
Respondent 2: & $\begin{array}{l}\text { Relates to packaging material, recyclable, renewable, biodegradable, and waste } \\
\text { collection } \\
\text { Respondent 3: }\end{array}$ \\
& $\begin{array}{l}\text { Made with recyclable materials, sustainably sourced materials, and produced } \\
\text { with renewable energy }\end{array}$ \\
\hline
\end{tabular}

Table 5 shows the respondent 1 and 2 have the similar input about how their companies start to apply eco-

friendly packaging, but respondent 3 did not have similar input with respondent 1 and 2 .

Table 5. How your company starts to apply eco-friendly packaging?

\begin{tabular}{ll}
\hline Respondents & Answers \\
\hline Respondent 1: & $\begin{array}{l}\text { Environment surrounding raise with awareness and concern about } \\
\text { environmental issue. }\end{array}$ \\
Respondent 2: & $\begin{array}{l}\text { Figure out the environment awareness and issue } \\
\text { Respondent 3: }\end{array}$ \\
& $\begin{array}{l}\text { Working with their packaging suppliers to use more recyclable material in } \\
\text { producing the packaging material }\end{array}$ \\
\hline
\end{tabular}

Table 6 shows all respondents have difference answer for "when your company starts to apply eco-friendly packaging". This is because different companies have different practices.

Table 6. When your company start to apply eco-friendly packaging?

\begin{tabular}{ll}
\hline Respondents & Answers \\
\hline Respondent 1: & 4 or 5 years \\
Respondent 2: & 7 years \\
Respondent 3: & N/A (few years back) \\
\hline
\end{tabular}

Table 7 shows there is no any similarity between all respondents, because this is asking their own perception on eco-friendly packaging and sustainable supply chain management.

Table 7. How do you perceive eco-friendly packaging and sustainable supply chain management?

\begin{tabular}{ll}
\hline Respondents & Answers \\
\hline Respondent 1: & $\begin{array}{l}\text { Require collaboration for each other to work together in terms of shelf-life, } \\
\text { production, workers and planning }\end{array}$ \\
Respondent 2: & Importance between each other in terms of cost effectiveness \\
Respondent 3: & Ensure the sustainability of environment and people \\
\hline
\end{tabular}

Table 8 shows respondent 1 and 3 have similar input where stated that eco-friendly packaging helps the company towards sustainable supply chain management, but respondent 3 stated that eco-friendly packaging help to generate supply chain efficiency. 
Table 8. How would the eco-friendly packaging used to influence the company's operations? Respondents Answers

Respondent 1: $\quad$ Eco-friendly packaging help to achieve sustainable supply chain management

Respondent 2: $\quad$ Unilever's operations are directed affect towards the sustainable living goals

Respondent 3: $\quad$ Generate supply chain efficiency

Table 9 shows respondent 1 and 2 have a similar opinion on the differences before and after implementation of eco-friendly packaging, but respondent 3 has different opinion.

Table 9. What are the differences between before and after implement the eco-friendly packaging?

\begin{tabular}{cl}
\hline Respondents & Answers \\
\hline Respondent 1: & Corporate social respo \\
Respondent 2: & Nestle are doing an ef \\
Respondent 3: & Amount of waste or m \\
\hline Benefit of eco-friendly packaging in sustainable \\
supply chain management to the organization.
\end{tabular}
Answers

Corporate social responsibility

Nestle are doing an effort for the society and environment

Respondent 2:

terial that is used will be significantly reduced

reduction for conversion process. Respondent 2 mentioned eco-friendly packaging can contribute costreduction for logistics activities.

Table 10 shows all respondents agree eco-friendly packaging contribute to cost-reduction, respondent 1 and 3 mentioned eco-friendly packaging can contribute cost-

Table 10. How does eco-friendly packaging contribute to cost reduction in sustainable supply chain management?

\begin{tabular}{cl}
\hline Respondents & Answers \\
\hline Respondent 1: & $\begin{array}{l}\text { Reduce the conversion cost by using a light packaging material. In logistics, it } \\
\text { can utilize the space and capacity. For shipment can contribute to cost } \\
\text { reduction }\end{array}$ \\
Respondent 2: & $\begin{array}{l}\text { Contribute fewer inventories, utilize warehouse space and generate cost } \\
\text { reduction } \\
\text { Respondent 3: }\end{array}$ \\
& $\begin{array}{l}\text { Eco-friendly packaging contribute low cost for the packaging were used with } \\
\text { less material }\end{array}$ \\
\hline
\end{tabular}

Table 11 shows all respondents agree eco-friendly packaging contribute to brand image. Respondent 1 and 2 mentioned eco-friendly packaging could attract more customers to buy. Respondent 1 and 3 mentioned ecofriendly packaging could generate positive image to the brand.

Table 11. How does eco-friendly packaging contribute to brand image in sustainable supply chain management?

\begin{tabular}{cl}
\hline Respondents & Answers \\
\hline Respondent 1: & $\begin{array}{l}\text { Attract more customers to buy. Positive image that have contribute efforts to } \\
\text { the society and environment }\end{array}$ \\
Respondent 2: & $\begin{array}{l}\text { Attract the consumer approach to purchase. Shows an effort and responsibility } \\
\text { to the society and environment }\end{array}$ \\
Respondent 3: & Generate a positive impact on the brand image \\
\hline
\end{tabular}

Table 12 show the respondent 1 and 2 agree eco-friendly packaging can contribute to legal compliance, but respondent 3 did not have comments on legal compliance.

Table 12. How does eco-friendly packaging contribute to legal compliance in sustainable supply chain management?

$\begin{array}{ll}\text { Respondents } & \text { Answers } \\ \text { Respondent 1: } & \begin{array}{l}\text { Allow company do not spend any effort on making changes or adjustment } \\ \text { anymore when the company started to follow the legal compliances }\end{array} \\ \text { Respondent 2: } & \begin{array}{l}\text { Prevent time waste on making adjustment with the legal compliance in the } \\ \text { future }\end{array} \\ \text { Respondent 3: } & \text { No comments on legal compliance }\end{array}$

Table 13 shows all respondents agree eco-friendly packaging contribute to environmental friendly.

Table 13. How does eco-friendly packaging contribute to environmental friendly in sustainable supply chain management?

Respondents Answers

Respondent 1: Contribute to environmental friendly through recyclable material that can be 
disposing

Respondent 2:

Contribute environmental friendly from reducing the number of trips

Respondent 3:

Reducing environmental impact by doing waste reduction, reusing and recycling

The implication of this study will be that FMCG industry will be able to identify and aware the benefits of ecofriendly packaging on sustainable supply chain management. This would mean that FMCG industry should consider implement eco-friendly packaging which bring the benefits to the company business itself and environment. The reason being, all benefits have a strong relationship in between sustainable supply chain management based on conducted analysis making the benefits of eco-friendly packaging that respondents' answer as a valid parameter to be used in FMCG industry. Subsequently, FMCG industry should also carry out more types of eco-friendly packaging to develop more successful sustainable supply chain management. This would enable them to achieve successful sustainable supply chain management as the benefits have a strong relationship with the benefits of eco-friendly packaging based on the respondent's answer.

\section{CONCLUSION}

The purpose of this study is to identify the benefits of eco-friendly packaging on sustainable supply chain management among FMCG industry. There are minor dissimilarities which is different perspective but in the same point of view. There are four benefits such as cost reduction, brand image, legal compliance, and environmental friendly that bring benefit to FMCG industry effectively. There is a direct relationship in which the benefit of eco-friendly packaging brings the company in developing more sustainable supply chain management. In this respect, FMCG industry are strongly consider implementing eco-friendly packaging in believe that the benefits will achieve sustainable supply chain management.

\section{References}

1. MilataryNews. 2017. FMCG Packaging Market to Increase at Steady Growth Rate. Retrieved 24 May, 2018 from http:/www.militarytechnologies.net/2017/01/20/fmcg-packagingmarket-to-increase-at-steadygrowth-rate/

2. Mehmet, A. I. and Surendra, M. G. 2009. Environmentally conscious manufacturing and product recovery (ECMPRO): A review of the state of the art. Journal of Environmental Management, 563-591.

3. Qureshi, W. 2017. FMCG giants launch initiative to recycle $70 \%$ of global plastic packaging. Retrieved May 25, 2018 from http:/www.packagingnews.co.uk/news/environmen t/industry-group-launchesinitiative-to-recycle-70-ofglobal-plastic-packaging-16-01-2017

4. WWF. 2016. WWF launches new Sustainability
Guide to encourage sustainable FMCG products in Asia. Retrieved 24 May, 2018 from http://wwf.panda.org/?265570/WWF-launches-newSustainability-Guide-toencourage-sustainableFMCG-products-in-Asia

5. Menon, P. 2016. Selangor government urges councils to provide traders with alternative food packaging ideas. Retrieved 23 May, 208 from http://www.thestar.com.my/metro/community/2016/ 05/31/easing-people-intonopolystyrene-waysselangor-government-urges-councils-to-providetraders-with-alt/

6. PakFactory. 2017. Eco-Friendly Packaging Can Improve Sales \& Encourage Reuse. Retrieved 23 May, 2018 from http://www.triplepundit.com/podium/friendlypackag ing-can-improve-sales-encourage-reuse/

7. Cetinkaya, B., Cuthbertson, B., Ewner, G., KlassWissing, T., Piotrowicz, W. and Tyssen, C. 2011. Sustainable Supply Chain Management: Practical Ideas for Moving Towards Best Practices. Springer.

8. Norani Nordin, Hasbullah Ashari, and Mohamad Farizal Rajemi. A Case Study of Sustainable Manufacturing Practices. Journal of Advanced Management Science, 2 (1)

9. Selvachandran, G., Quek S.G., Smarandache, F. and Broumi, S. 2018. An extended technique for order preference by similarity to an ideal solution (TOPSIS) with maximizing deviation method based on integrated weight measure for single-valued neutrosophic sets. Symmetry, 10, 236-252. DOI: 10.3390/sym10070236.

10. Selvachandran, G. and Peng, X. D. 2018. A modified TOPSIS method based on vague parameterized vague soft sets and its application to supplier selection problems. Neural Computing and Applications, 1-16. DOI: https://doi.org/10.1007/s00521-018-3409-1.

11. Team, F. 2014. When to Use Them, and How They Can Benefit Your Organization! Retrieved 25 May, 2018 from http://fluidsurveys.com/university/3types-surveyresearch-use-can-benefit-organization/

12. Dilanthi, A. 2002. Quantitative and Qualitative Research in the Built Environment: Application of "Mixed" Research Approach. International Journal of Productivity and Performance Management, 1731.

13. Sekaran, U. and Bougie, R. 2010. Research Methods for Business: A Skill-Building Approach. United Kingdom: John Wiley \& Sons Ltd.

14. Wahab, S.N., Bahar, N. \& Mat Radzi, N.A. (2019). An Inquiry on Knowledge Management in Thirdparty Logistics Companies. International Journal of Business Innovation and Research, DOI: 10.1504/IJBIR.2020.10024101. 
15. Bryman, A. and Bell, E. 2011. Business Research Methods. New York: Oxford University

16. Wahab, S.N., Rajendran, S.D., Yeah N.K., \& Deng Y. (2017). Antecedents Influencing E-Service Quality towards Customer Loyalty among Malaysian Online Shoppers. 3rd International Conference on Advanced Research in Business and Social Sciences, 29-30 March, 337-346, Langkawi Malaysia.

17. Wong, C. H., Tan, G. W. H., Tan, B. I. and Ooi, K. B. 2015. Mobile Advertising: The Changing Landscape of the Advertising Industry. Telematics and Informatics, 32 (4), 720-734.

18. Wahab, S.N., Lay, Y.F., Koay, W.L., \& Hussin, A.A.A, (2019). Usage of Pedestrian Bridge among the Urban Commuters in Kuala Lumpur. International Journal of Operational Research, DOI: 10.1504/IJOR.2021.10019276.

19. Wahab, S.N., \& Khong W.L. (2018). Multiple Linear Regression Modelling of Parcels' Distribution Design Factors and online Shopping Customer Satisfaction. International Journal of Modelling in Operations Management, 7(2), 95-110. 